GeOGRAFARESO

Revista do Programa de

Pós-Graduação em Geografia e do Departamento de Geografia da UFES

JANEIRO - JUNHD, ZQZI

ISSN 2175-3709

\section{CORPO E MUNDO: DEVANEIOS EXISTENCIAIS EM TEMPOS PANDÊMICOS}

\section{CUERPO Y MUNDO: PENSAMIENTOS EXISTENCIALES PROFUNDOS EN TIEMPOS DE PANDEMIA Y COVID-19 \\ BODY AND WORLD: DEEP EXISTENTIAL THOUGHTS IN
PANDEMIC AND COVID-19 TIMES CORPS ET MONDE: PENSÉES EXISTENTIELLES PRO- FONDES EN PANDÉMIE ET COVID-19}

\section{RESUMO}

De que maneira a relação corpo e mundo nos ajudam a pensar o atual momento pandêmico e, além disso, quais seriam suas implicações existenciais, isto é, de que maneira a dada situação influencia em nosso sentido de vida? Essa é nossa pergunta norteadora. O presente artigo/ensaio é uma proposta de incitar reflexões outras ou um convite ao diálogo a respeito de dimensões nas quais atravessam no ser e sentido de ser-no-mundo. Casa, corpo, mundo e tempo são exemplos de dimensões que, há pelo menos 1 ano, vem exigindo um novo posicionamento referente aos nossos valores humanos. Dessa maneira, pretende-se trazer a reflexão a distinção entre "pandemias" e COVID-19, ao modo que a primeira é o todo dos problemas estruturais e simbólicos evidenciados pelo segundo.

palavras-Chave: Angústia. Experiência do tempo. Sentido de vida.

\section{FELIPE KEVIN RAMOS DA}

\section{SILVA}

Universidade Estadual de

Campinas (UNICAMP).

Professor da Rede Pitágoras

de Ensino, Juruti, PA.

felipekevin.gegrafia回gmail.cam

Artigo recebido em:

IG/05/202|

Artigo aprovado em:

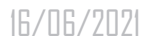

\section{RESUMEN}

¿Cómo nos ayuda la relación entre cuerpo y mundo a pensar en el momento pandémico actual y, además, cuáles serían sus implicaciones existenciales, es decir, cómo influye la situación dada en nuestro sentido de la vida? Ésta es nuestra pregunta guía. El presente artículo / ensayo es una propuesta para incitar otras reflexiones o una invitación al diálogo sobre las dimensiones en las que se cruzan en el ser y el sentido del ser-en-el-mundo. Hogar, cuerpo, mundo y tiempo son ejemplos de dimensiones que, desde hace al menos 1 año, vienen exigiendo un nuevo posicionamiento respecto a nuestros valores humanos. De esta forma, se pretende reflexionar sobre la distinción entre "pandemia" y COVID-19, en la forma en que la primera es el conjunto de problemas estructurales y simbólicos que evidencia la segunda.

palabras-clave: Angustia. Experiencia en el tiempo. Sentido de vida. 


\section{A B STR ACT}

How does the relationship between body and world help us to think about the current pandemic moment and, furthermore, what would be its existential implications, that is, how does the given situation influence our sense of life? This is our guiding question. The present article / essay is a proposal to incite other reflections or an invitation to dialogue regarding dimensions in which they cross in being and the sense of being-in-the-world. Home, body, world and time are examples of dimensions that, for at least 1 year, have been demanding a new position regarding our human values. In this way, it is intended to bring to reflection the distinction between "pandemic" and COVID-19, in the way that the first is the whole of the structural and symbolic problems evidenced by the second. KEYWORDS: Anguish. Time experience. Sense of life.

\section{RÉSUMÉ}

Comment la relation entre le corps et le monde nous aide-t-elle à réfléchir au moment actuel de la pandémie et, en outre, quelles seraient ses implications existentielles, c'est-à-dire comment la situation donnée influence-t-elle notre sens de la vie? Telle est notre question directrice. Le présent article / essai est une proposition pour susciter d'autres réflexions ou une invitation au dialogue sur les dimensions dans lesquelles ils se croisent dans l'être et le sens d'être-au-monde. La maison, le corps, le monde et le temps sont des exemples de dimensions qui, depuis au moins 1 an, réclament une nouvelle position sur nos valeurs humaines. De cette manière, il entend faire réfléchir la distinction entre «pandémie» et COVID-19, de la même manière que le premier est l'ensemble des problèmes structurels et symboliques mis en évidence par le second. MOTS CLÉs: angoisse. Expérience du temps. Sens de la vie.

\section{INTRODUÇÃO}

"Nas horas mortas de cada dia Procuro ansioso a alegria Que desgarrada desapareceu Deixando saudades nos olhos meus O amor já era Felicidade voou O egoísmo impera Que mundo estou? Estou num mundo vazio Onde pouco se fala de amor Passo as noites no frio Mergulhado na solidão e na dor Essa dor que sinto agora Que me faz em tudo pensar Sou uma alma que chora Por não ter o seu olhar"

Ted $\operatorname{Max}^{1}$
Esta música ecoa por todo artigo e descreve um sentimento que, ao menos para mim, desvela uma relação muito próxima - embora negada, em muitos casos - entre corpo e mundo ${ }^{2}$. Um diálogo mediado pelo tempo: estou em meu quintal, ouvindo um brega da década de 1980, muito comum entre nós paraenses de Belém, se chama "Por não ter teu olhar", do cantor Teddy Max. Neste dia de domingo, um domingo ensolarado, encontro minha solitude, uma oportuni-
1. Ted Max - Por não ter o seu olhar (LP 1987). Postado por Acervo de Disco em 14 jul. de 2013. 2 minutos e 44 segundos. Disponivel em https:// www. youtube.com / watch? $v=Y a Z R n \_v 6 l a s$. Acesso no dia 18 fev. 2021.

2. A noção de "corpo" e "mundo" é desenvolvida aqui a partir das interpretações de Merleau-Ponty em sua Fenomenologia da percepção (1994).

\section{GenGrafares}

Revista do Programa de Pós-Graduação em Geografia e do Departamento de Geografia da UFES

JANEIRO - UNHO, 2021

ISSN 2175-370S 


\section{GenGRAFARESO}

Revista do Programa de

Pós-Graduação em Geografia e do Departamento de Geografia da UFES

Janeiro-Junho, 2021

ISSN 2175-3709

3. O Professor Felipe Sampaio de Freitas escreve: “... Sob um âmbito pragmático e analítico, em se tratando de investidas de acesso inclusivo, diríamos que se deve levar em conta a situação política do Brasil, ou seja, suas controvérsias, contradições e problemáticas, principalmente quando o assunto esbarra nos níveis exacerbados da corrupção política brasileira" (FREITAS, 2020a, p. 204).

4. Sou Professor de geografia do Ensino Básico e Pré-Enem há cinco anos da rede privada de ensino no Estado do Pará.

5. Entendo por "habitar" como sendo o horizonte fundamental da proteção gestado pelo sentido espacial da casa, conforme Bachelard (1998).

6. Sou professor, repito, e por isso meu quarto se transformou em sala de aula, por exemplo. O meu corpo, afetado por um tempo ainda mais perverso do trabalho, reclama, por meio das dores nas costas, ansiedade e possivel depressão, por soluções imediatas para que este campo de concentração velado chegue ao seu fim. dade viva de escrever alguma coisa que seja, talvez, minimamente interessante para quem se dispor a ler a respeito da relação corpo e mundo e suas implicações existenciais em tempos de COVID-19.

E cabe aqui, portanto, evidenciar a diferença entre "pandemias" e o vírus mortal que já ceifou, porém não sozinho, mas com ajuda sistemática dos discursos negacionistas, mais de 500 mil vidas brasileiras até o momento. Logo, falar de "pandemias", como sugere o título deste artigo/ensaio, é a premissa na qual, tratando-se de Brasil, existem problemas que adoecem cotidianamente nosso corpo, alma, lugares, do próprio sentido, inclusive, da casa e dos modos de habitar esse espaço.

É um projeto de adoecimento que ganhou muita expressão no atual Governo Federal, ao modo que o vírus mortal, chamado de COVID-19, é mais uma peça desse jogo da morte. Sem vacinas suficientes e com o desmonte do $\mathrm{SUS}^{3}$, conforme Freitas (2020a), e outras ações, devanear mediante essa realidade é, de certo modo, uma maneira de manter a saúde mental e do corpo, sem, no entanto, negar o que de fato está acontecendo. O filósofo e psiquiatra Victor Frankl nos ensina que a "pressão" da realidade é sadia, nos situa no mundo, mas, no entanto, até que ponto podemos suportar tal "pressão"?

Daí vai ouvir/sentir um brega... Na solitude de cada dia, um encontro comigo mesmo, sentidos da vida. Sinto-me vivo e, ao mesmo tempo, desamparado. Arremessado! Ouvindo
Teddy Max, percebo fortes semelhanças com o atual momento de pandemias: pandemia política, social, mental e viral. Entre o tempo na solitude e o tempo do trabalho, e o tanto que este último nos exige, sobretudo hoje - onde já acordo, às $7 \mathrm{~h} 30 \mathrm{~min}$, com uma mensagem no celular dizendo que preciso rever algumas notas ${ }^{4}$ - recorro ao corpo enquanto horizonte da experiência do sentido de tempo e espaço. Profundas reflexões veem ao meu encontro na tentativa de restabelecer este corpo com o próprio sentido da vida, mediante as significativas transformações que me/ nos atravessam. Haveria de alguma maneira, um tipo de adoecimento existencial do corpo e, caso sim, quais seriam suas implicações existenciais?

O sentido próprio do corpo no qual, há pelo menos um ano aprendemos a (re)encontrar, a nos reeducar, melhor dizendo, reverbera em uma pedagogia que não é nova, porém esquecida por muitos, e que na qual ressurge e reclama o seu lugar. Mas reclama de forma rápida. Por isso é doloroso, às vezes, vivenciar a casa em sua plenitude, inclusive como lugar do trabalho, fazendo-nos, desta maneira, mesmo que inconscientemente, reaprender o sentindo próprio do habitar ${ }^{5}$. Isso é doloroso ${ }^{6}$.

O brega envolvente do cantor paraense Teddy Max, embora produzido em um outro momento, chama minha atenção no sentido na qual as palavras, ainda assim, ganham sentido neste atual momento 
de pandemias. As palavras da música chamam atenção para as circunstâncias de um sujeito que procura ansiosamente pela alegria, em meio ao egoísmo que impera, onde pouco se fala de amor, afetos sinceros; onde, mergulhado na solidão e na dor, clama pelo contato do outro que, trazendo para o atual momento, está distante... isolado... "Que mundo estou?" - pergunta o cantor. Uma pergunta que venho me fazendo nos últimos tempos, há pelo menos 1 ano.

"Sou uma alma que chora... por não ter o seu olhar". Mas quem não é, hoje, uma alma chorosa, mediante a distância de familiares, amigos, amor ou amores por conta da atual situação imposta pelo vírus mortal? Fazemos nossa parte. Cada um à sua maneira, e embora muitos ainda insistam em dizer que "estamos no mesmo barco", sabemos que isso é um mito, típico de uma sociedade elitista e meritocrática. De todo modo, os ventos que sopram por esses lados da Terra, trazem situações que evocam reflexões próprias de um momento no qual, ao menos para mim, convida o corpo como ícone referencial para repensar o sentido da vida em nossa "condição terrestre" (DARDEL, 2015).

No meu quarto "isolado" do mundo, recrio o sentido da vida; tenho a chance de reaprender a ver a mim mesmo, no mundo. A lucidez da música é um prisma sensorial que nos lança à reflexão de nossas responsabilidades, não são somente jurídicas, mas, ontoló- gicas e existenciais. Algo que me fez pensar da seguinte maneira: o que acontece entre o nascimento e a morte? Este é um devaneio pensado profundamente $\mathrm{em}$ realidade como proposta de um mergulho lúcido, crítico e sensível em prol do que muitas vezes escapa de nossa educação puramente racional, exigindo de nós mesmos um posicionamento de "pausa no tempo", como diria Tuan (2013), para (re)sentir nossa "carnalidade geográfica", conforme Marandola Jr. (2020), sobretudo hoje.

Como já dizia Sartre (2014a), "a existência precede a essência" e, partindo desse princípio, o próprio sentido da vida, por sua vez, reverbera sua conotação humanista, pois traz ao pensamento a fundamental importância da liberdade como responsabilidade humana, ou seja, o entendimento de que todas as minhas ações podem gerar consequências para o mim e para o outro.

Neste mergulho, venho propor uma reflexão à respeito de um diálogo fundamental, a relação corpo-mundo. Duas dimensões importantes para o entendimento no que diz respeito às novas exigências proporcionadas pelas pandêmicas articulações políticas/religiosas $^{7} /$ econômicas da morte do governo bolsonarista com o COVID-19. Dimensões essas que implicam diretamente em nossas vidas e, por assim dizer, nos modos como lidamos com esse processo. Dessa maneira, o filósofo e psiquiatra austríaco Victor Frankl (19051997) se destaca por suas ex-
7. Essa interpretação da realidade brasileira nos faz lembrar Nietzsche em O Anticristo: "... no fundo, houve apenas um cristão, e ele morreu na cruz [...] $O$ "cristão", isso que há dois milênios se chama cristão, não passa de um malentendido psicológico de si mesmo" (NIETZSCHE, 2007, p. 45).

\section{Gengrafaresty}

Revista do Programa de Pós-Graduação em Geografia e do Departamento de Geografia da UFES

Janeiro-Junho, 2021 ISSN 2175-3709 
GEOGRAFARESO

Revista do Programa de Pós-Graduação em Geografia e do Departamento de Geografia da UFES

Janeiro-Junho, 2021

ISSN 2175-3709

8. Belchior - Comentário a respeito de Jonh (1999). 5 minutos e 03 segundos. Disponivel em https: // www. youtube.com / watch? $v=$ f6 JOMFnzITw. Acesso no dia 14 de maio de 2021. periências como prisioneiro em campos de concentrações nazistas.

Não pretendo trazer dados, isso já é muito evidente e óbvio: o Governo Bolsonarista é incompetente e pouco se importa com a vida de seu povo, ao modo que os últimos dados evidenciam um número crescente de mortes por dia. Pretendo, portanto, parar um tempo para refletir e, caso esse texto faça algum ruído, progredir para possíveis ações práticas que estejam efetivamente ligadas à consciência de um sentido de corpo-mundo mais sensível à nossa condição terrestre.

\section{A EXPERIÊNCIA CORPÓREA DO TEMPO}

“ João, o tempo andou mexendo com a gente, sim..."

Belchior $^{8}$

Uma pedagogia reclama seu lugar. Uma pedagogia da sensível experiência do tempo que precisa ser resgatada como horizonte de sentido. O tempo todos os dias atravessa meu corpo e me conduz a ansiedade, ao quase desespero mediante as tantas tarefas cotidianas que envolvem a vida - em meu caso - de um professor. Deveríamos ter aprendido algo com tudo isso. No entanto, me parece que as forças perversas da extrema produtividade multifuncional conseguiram sua legitimidade e, por isso, o que deveríamos está lutando contra está ganhando mais força e de forma permissiva.

O cantor Belchior (1946-
2017), assim mesmo como Santo Agostinho (354 d.C. -430 d.C.), nos convidam à reflexões necessárias para entender que o tempo, considerando toda sua fluidez, é parte constitutiva de nossa existência, de tal maneira que, dependendo da situação, mexe conosco como forma de anunciar a importância da "consciência da consciência" de nós mesmos, conforme Husserl (2006). Por outro lado, me parece que essa "consciência transcendental" está cada vez mais reduzida ao imediatismo. O tempo como forma volátil da existência, vem se (re)configurando como estratégia do "mundo do trabalho", tal como entende Harvey (2009), deslocando, por assim dizer, nossa consciência para liquidez das relações humanas.

Han (2017) entende esse processo como "liberdade paradoxal" que, segundo filósofo, elimina e limita, em muitos casos, a imunização do sentido de "estranheza" de um mundo (sociedade) que vem se constituído, pelo menos desde o século $\mathrm{XX}$, por fatores indutivos onde a experiência do tempo se reduz ao desempenho produtivo, contribuindo, desta maneira, para os processos estruturas e simbólicos onde o sentido de humanidade está fortemente vinculado à materialidade, ao consumo/esgotamento de si como modo de vida. Daí o sentimento de satisfação por trabalhar o dia todo, de domingo a domingo, acreditando ser uma espécie de empreendedor de si mesmo (HAN, 2017; FREITAS, 2020b).

Mas tudo isso é pura ilu- 
são, pois além do que foi dito, o "tempo livre" incorpora também a ideia caduca de que, em tempos de COVID-19, trabalhar em casa é sinônimo de sorte ou privilégio. Não é sorte por que o/a trabalhador/a assalariado/a não sobrevive de piedade da empresa empregadora. Não é privilégio porque todos os dias eu, assim como outros/as colegas professores/as, dormimos mais tarde do que de costume produzindo aulas, organizando planilhas e relatórios; acordamos mais cedo, com mensagens absurdas de pais/responsáveis e lideranças escolares cobrando situações que, muitas vezes, fogem de nossas responsabilidades.

A ideia de "tempo livre" por trabalhar em casa, o famoso home office, é um absurdo e interfere diretamente em nossas vidas e, inclusive, no próprio sentido da vida, na forma como experimentamos o tempo, ou seja, a nós mesmos. É um absurdo, pois exige do corpo uma restruturação helenística para que os espaços da casa sejam remodelados em prol de um "lugar para trabalhar". Gastamos dinheiro com reformas, a conta de energia elétrica, que já não é acessível, se torna ainda mais abusiva: notebooks, celulares e ventiladores/ar condicionados ligados quase 24 horas/dia. O salário continua o mesmo, sem qualquer alteração positiva para tentar, minimamente, compensar as despesas extras. Por estas e outras razões, a ideia de privilégio é uma falácia.

Esses são devaneios de uma realidade e, evidentemente, uma perspectiva perante há tantas outras. Há necessidade de estudos que incorporem outras realidades como ícones referenciais para repensar um projeto de "tempo livre" que, ao invés de nos proporcionar, de fato, liberdade, nos lança para o próprio adoecimento psíquico. Essa "liberdade coercitiva", como diria Han (2017, p. 30), é um golpe estratégico por que incorpora justamente nossas vaidades competitivas e nosso ego superlativo em relação ao outro: "essa é mais eficiente que uma exploração do outro, pois caminha de mãos dadas com o sentimento de liberdade" (Idem).

Em meio a esses devaneios, do brega à filosofia, o tempo sempre foi e é um problema, no sentido de que este grande arquétipo nos lança ao que, muitas vezes, queremos negar: nossa finitude, ao modo que esta traz consigo - do ponto de vista fenomenológico - o sentido de responsabilidade e, portanto, a inquieta reflexão sobre o sentido da vida, conforme Frankl (1987), ao desenvolver a "logoterapia". Isso é interessante, pois quantos de nós, por vias de nossa educação ocidental, paramos para pensar a respeito do "sentido da vida"? "Isso é coisa de gente que não tem o que fazer da vida" - dizem alguns, reduzindo a vontade de sentido de viver a meros estímulos biológicos e psíquicos. Algo que, inclusive, segundo Frankl (1987), caracteriza a sociedade ocidental, tendenciosa aos
9. "O termo logos é uma palavra grega e significa 'sentido'! A logoterapia, ou, como tem sido chamada por alguns autores, a 'Terceira Escola Vienense de Psicoterapia', concentrase no sentido da existência humana, bem como na busca por este sentido" (FRANKL, 1987, p. 116).

\section{Gengrafaress}

Revista do Programa de Pós-Graduação em Geografia e do Departamento de Geografia da UFES

Janeiro-Junho, 2021 ISSN 2175-3709 


\section{GenGRAFARESS}

Revista do Programa de Pós-Graduação em Geografia e do Departamento de Geografia da UFES

Janeiro-Junho, 2021

ISSN 2175-3709

10. "Pensar", aqui, referese ao sentimento de estar engajado a um projeto e se fazer parte deste, conforme Lévinas (1997). desequilíbrios neurais.

Pensar ${ }^{10}$ a respeito da vida inclui, mesmo que timidamente, pensar a experiência que temos com o tempo, trazendo a superfície nosso drama histórico, que é o fato de que um dia iremos encontrar nossa finitude. Isso é um fato que pode, a princípio, parecer óbvio, pois demonstra àquilo que todos têm em comum. Não obstante, há necessidade de destacar a consciência reflexiva no que diz respeito ao sentido da morte, que é diferente de simplesmente ter "noção" de nossa finitude. Daí a experiência do tempo-limite e como ela se modifica mediante aos novos eventos, afetando nossos corpos e, inclusive, nosso ego. Odiamos pensar a respeito do sentido por que isso nos leva a cogitar nossa finitude e esta, por sua vez, nos direcionando para o fim de nossas vaidades. A morte afeta, profundamente, nosso ego.

Certa vez o geógrafo sino-americano Yi-Fu Tuan disse: "[...] pensar e planejar ajudam a desenvolver a habilidade espacial do homem [e da mulher] no sentido de movimentos corporais ágeis. " (TUAN, 2013 , p. 244). Isso implica nos seguimentos da vida que exigem do corpo uma "habilidade espacial" capaz de sentir as circunstâncias que o afeta. Mediante a isso, podemos dialogar com Victor Frankl (1905-1997) ao escrever, em 1945, uma obra conhecida mundialmente por ser um relato de suas experiências em campos de concentração durante o período nazista. De um modo geral, o psiquiatra, por meio de suas narrativas, relata as formas de como e o que sentiu e vivenciou em meio ao tempo-limite imposto pelos espaços sufocantes que são os campos de concentração:

.. Perguntei a companheiros que
já estavam há mais tempo no cam-
po de concentração onde poderia
ter ido parar meu amigo P. - "Ele
foi mandado para o outro lado?"
- "Sim", respondi. - "Então po-
des vê-lo ali", disseram. "Onde?"
Uma mão aponta para uma chami-
né distante algumas centenas de
metros, da qual sobe assustadora
e alta labareda pelo imenso e cin-
zento céu polonês, para se extin-
guir em tenebrosa nuvem de fu-
maça. "O que há ali?" - "Ali o teu
amigo está voando para o céu",
é a reposta grosseira. Continuo
sem entender; mas logo come-
ço a compreender, assim que me
"iniciam" no assunto (FRANKL,
1987, p. 26).

Victor Frankl foi ao encontro de sua morte por várias vezes, sentiu sua finitude e, em sua humanidade, demonstra como o tempo, ou melhor, a experiência do tempo-limite nesses espaços desvela a fundamental importância de estratégias que clamam por um sentido para viver. É um verbo encarnado no qual o corpo, atravessado por uma situação catastrófica, suplica por uma resposta, adoecimento que transcende a sensação física, pois, agora, é uma dor existencial, mata em vida: "Por que eu?" "O que eu fiz para merecer isso?" "Será castigo de 
Deus?". Por outro lado, Frank (1987) acredita que superar uma situação dessas só depende, primeiramente, de nós mesmos.

Evidentemente, não é algo tão simples, pois envolvem várias outras dimensões. Porém, é possível na medida em que se tem uma razão para viver (FRANKL, 1987). É como se estivéssemos dialogando com o tempo... Experimentando-o, entre o sabor amargo e doce, entre-lugares. Em meio a essa experiência, talvez seja interessante observar como ele, Victor Frankl, percebeu a si mesmo mergulhado nesse tempo-limite que atravessava seu sentido de ser, no mundo, e, ao mesmo, como essa situação transformou seu corpo como referência escalar de sua existência e narrativas de vida.

O Professor Arnin Braga, sobre essas experiências de Victor Frankl, nos esclarece, a partir de uma leitura fenomenológica, o modo como nossa existência está fortemente articulado com o sentido histórico de nossas bases ancestrais ou tradicionais que, inclusive, dizem muito a respeito de nossas narrativas do presente. No entanto é algo que no decorrer da história ocidental vem se perdendo, desvelando um dos dramas de nossa sociedade:

Em outras palavras, à medida que o ser humano foi desenvolvendo-se ao longo da história, ele foi perdendo alguns instintos básicos que asseguravam sua existência. Sentindo-se constantemente separado de todo o mundo natural que o rodeia, a humanidade sempre experimentou certo vazio existencial e espanto frente à vida, justamente por não encontrar no próprio instinto nenhum fator referencial interno que possa guiar seus comportamentos. No entanto, Frankl também ressalta que atualmente este vazio existencial e tédio frente à existência estão sendo reforçados por um novo contexto cultural: a crise das tradições e "grandes relatos", que deixam ao homem contemporâneo sem referenciais externos que possam guiar suas ações (BRAGA, 2020, p. 70-71).

A similaridade do presente com o contexto vivenciado por Frankl (1987) nos revela que a história pode se repetir, não da mesma forma e sentido, mas em seus pressupostos estruturais e simbólicos. Desta maneira, Braga (2020) dialoga com o pensamento de Frankl (1987) e nos convida para repensar o sentido do "tédio" e suas dimensões em contexto de COVID-19. Além disso, há de se considerar a consciência do estatuto histórico de nossa existência, do que somos hoje, tendo por fim um esclarecimento capaz de nos conduzir para importância do ser-no-mundo, do verbo encarnado enquanto corporeidade.

Se pararmos para pensar melhor a respeito de nossa condição temporal, podemos perceber, cada um à sua maneira, uma nítida aproximação entre corpo-mundo, de tal maneira a nos perguntar: de que forma somos afetados pelos descasos da humanidade? Quero dizer, como as guerras, a fome, as doenças, o despre-

\section{GenGRAFARTSO}

Revista do Programa de Pós-Graduação em Geografia e do Departamento de Geografia da UFES

Janeiro-Junho, 2021

ISSN 2175-3709 


\section{GEOGRAFARESO}

Revista do Programa de

Pós-Graduação em Geografia e do Departamento de Geografia da UFES

Janeiro-Junho, 2021

ISSN 2175-3709

11. Crise humanitária e espiritual não no sentido teológico ou religioso, mas algo que busca evidenciar crises de comportamentos éticos, onde, por exemplo, o consumo, não só de objetos, mas, de pessoas também, tornam-se fontes subjetivadoras de atitudes e valores consigo mesmo e com outro. Krenak (2020), por exemplo, nos propõem um "resgate" de nossas ancestralidades como base de um humanismo capaz de considerar tanto o sentido de "ser humano" quanto nossas relações com o cosmo.

12. "O 'vazio existencial' se manifesta principalmente num estado de tédio. Agora podemos entender por que Schopenhaver disse que, aparentemente, a humanidade estava fadada a oscilar eternamente entre os dois extremos de angústia e tédio [...] Lastimável é que muitos deles não saberão o que fazer com seu tempo livre" (FRANKL, 1987, p. 123).

13. "Daí a divisão sexual do trabalho, que as relega ao trabalho invisibilizado e desvalorizado na casa e no cuidado dos filhos. Nós nunca refletimos acerca dessas hierarquias, assim como não refletimos sobre o ato de respirar. É isso que as faz las hierarquias poderosas: elas se tornam naturalizadas]. Esquecemos que tudo que foi criado por seres humanos também poder ser refeito por nós" (SOUZA, 2019, p. 23) paro de certos governantes, o descaso do poder público, os crimes de racismo, xenofobia, homofobia... De que maneira os cortes públicos para educação; a atuação perversa da polícia; a ignorância; os ataques à ciência; os grupos de extrema direita afetam nossos corpos?

Não é que uma coisa anule a outra. Mas, talvez, seja interessante repensar nossa postura enquanto cidadãos. Não somente do ponto de vista jurídico, mas ontológico e existencial, sobretudo se quisermos elaborar projetos humanistas em prol da vida digna. Dessa maneira, podemos devanear: Por que nos permitimos, muitas vezes, conforme Han (2017), ser mais tocados por "coisas" superficiais, como alcançar metas no trabalho ou ter a melhor nota da classe, do que, em nosso caso, pelo descompromisso do governo bolsonarista em relação à pandemia da COVID-19, ao modo que no Brasil já temos um rastro do possível adoecimento não só corpo, mas da alma e uma quase naturalização das mortes que só aumentam?

$\mathrm{Se}$ as respostas estiverem essencialmente vinculadas ao dinheiro, ao lucro, de que não alcançar metas leva ao fracasso no trabalho ou que "parar um momento" para analisar profundamente a atual situação política e social no Brasil seja "perda de tempo", estamos caminhando para um abismo onde a única salvação, talvez seja construir em praça pública uma estátua de narciso e declarar aos quatros ventos nossa mediocridade ética, social e política.

Afinal, percebo que nesta atual sociedade brasileira, não paramos de transformar tudo em nosso próprio desejo egoísta de ser, fruto de pura vaidade. É, digamos assim, uma busca pela qual nós também podemos transformar a realidade, seja em prol da vida digna como bem comum em sociedade ou a favor de interesses elitizados. Por outro lado, acaba que nossos corpos são muito mais afetados pelo desempenho do/no trabalho, por exemplo, do que pela crise humanitária e espiritual ${ }^{11}$ que vivenciamos há décadas, e que hoje, por assim dizer, ganha destaque por evidenciar, também, uma crise de consciência do corpo e do tempo.

A crise de consciência do corpo e do tempo pode estar associada ao que Frankl (1987) entende por "vazio existencial", evidenciando-se em massa a partir do sentimento do tédio ${ }^{12}$ que nunca foi devidamente apresentado em nossa educação brasileira. Essa relação inicial entre corpo-tempo-existência anuncia nossa fragilidade enquanto sociedade, que tem a ver com o campo político e psíquico, porém, não tão somente, ou seja, trata de um processo histórico, necessitando ser mais bem desenvolvido, conforme Souza (2019), ao trabalhar o senso de "hierarquia moral"13 como estrutura de poder simbólico no Brasil.

Nesse devaneio, os percursos históricos de nossa sociedade brasileira nos permitem 
analisar que a atual pandemia viral é, além do que demonstra ser, um fenômeno desencadeador de pandemias outras que, até então e por vias cada vez mais escancaradas, estavam/estão inseridas simbólico e estruturalmente em nossos valores, sejam eles políticos, morais e/ou sociais e, inclusive, em valores que omitem a reflexão do sentido da vida para além de uma realidade cada vez mais insuportável. São emoções despertadas nesse momento de incertezas que exigem do corpo outro comportamento (SARTRE, 2014b). Estamos dispostos a abrir mão de nossas vaidades?

Frankl (1987) já pensava que, pelo ritmo que a dita "sociedade moderna" estava caminhando, com a acelerada performance produtiva das máquinas industriais, o trabalhador médio poderia ter mais "horas de lazer". Entretanto, ao afirmar isso, Frankl (1987) também nos lança um desafio paradoxal ao questionar o sentido do "tempo livre" para esse trabalhador, afinal, o que fazer com ele, o "tempo livre"? Há um discurso que nasce em meio a esse desafio paradoxal e que merece um tratamento em destaque: "eu não tenho tempo..." - é o que muitos dizem mesmo estando deitados numa rede em um dia ensolarado... É, na verdade, o esgotamento do tempo de si mesmo, ou seja, a morte em vida.

$\mathrm{Na}$ atual sociedade em que vivemos, esse tipo de fala é comum. Se pararmos para pensar, não é o tempo que nos carece. $\mathrm{O}$ que nos falta é dis- posição para refletir a respeito de como esse tempo neurótico, adoecido nos afeta e, portanto, nos deixa doentes, depressivos, chatos e insensíveis com a dor outro. Conjuntamente a esse processo de reconhecimento do tempo neurótico, segundo Han (2017, p. 29), existe uma legitimidade por parte de todos nós, envolvidos nesse sistema imunológico que exclui qualquer "lamúria do indivíduo depressivo", entendido como um "inválido", pois este não mais atende as multitarefas da "sociedade do desempenho". Dessa maneira, o atual vírus-global nos apresenta várias outras pandemias, inclusive a pandemia da alma que nos adoece em diferentes lugares.

Somos o próprio tempo e quando este é apropriado pelo "mundo do trabalho" e legitimado por todos nós, adoecemos de forma a agradecer, acreditando que isso é realização de sucesso. Ter consciência disso é anunciar para si a passos largos de que somos responsáveis por tudo, inclusive pela nossa felicidade e destino de vida, conforme Frankl (1987). Evidentemente que isso é um processo muito difícil, sobretudo em uma sociedade imediatista como a nossa, onde estamos cercados de informações e distrações que acabam, por sua vez, nos cegando para o que de fato importa. Fiquemos atentos, pois estamos cada vez mais doentes. Não necessariamente acometidos de doenças físicas, mas emocionais e, portanto, neurais:

\section{GEOGRAFARESO}

Revista do Programa de Pós-Graduação em Geografia e do Departamento de Geografia da UFES

Janeiro-Junho, 2021

ISSN 2175-3709 


\section{GEOGRAFARESO}

Revista do Programa de

Pós-Graduação em Geografia e do Departamento de Geografia da UFES

Janeiro-Junho, 2021

ISSN 2175-3709

14. Conforme Han (2017, p.

14), "O desaparecimento

da alteridade significa

que vivemos numa época pobre de negatividades". O filósofo anuncia um possivel fim do outro pelo "excesso de positividade" que ele denomina de "violência da positividade", onde um sujeito se autoafirma sobre o outro, negando tanto o que é diferente quanto o que é igual.
Cada época possui suas enfermidades fundamentais. Desse modo, temos uma época bacteriológica que chegou ao seu fim com a descoberta dos antibióticos. Apesar do medo imenso que temos hoje de uma pandemia gripal, não vivemos numa época viral [...] Visto a partir da perspectiva patológica, o começo do século XXI não é definido como bacteriológico nem viral, mas neuronal. Doenças neuronais como a depressão, transtornos de déficit de atenção com síndrome de hiperatividade (TDAH), Transtorno de personalidade limítrofe (TPL) ou a Síndrome de Burnout (SB) determinam a paisagem patológica do começo do século XXI (HAN, 2017, p.7-8).

O filósofo sul coreano Byung-Chul Han, chama isso de "sociedade do cansaço", estimulada 24 horas por dia pelo bom desempenho multifuncional como modo de vida. O trabalho excessivo sobre o corpo é sentido como tempo-limite, ou seja, um processo sintomático capaz de gerar alterações comportamentais, e isso envolvem tanto o corpo quanto nossa capacidade de lidar com situações adversas, o que nos torna, em muitos casos, carrascos e vítimas de nós mesmos nesse modelo de vida.

Estamos falando que hoje, na pandemia político-viral, casos como depressão alcançaram números absurdos e, mediante a esse fenômeno patológico e social, há necessidade de estudos que possam compreender as razões disso em uma escala global (KOLA, et al., 2021). Partimos do princípio no qual o "mundo do trabalho" invadiu nossas casas e, portanto, nossa individuali- dade confundiu-se com a vida pública. Sendo algo legitimado por nós mesmos, mesmo que não dependa da gente. Isso gera desconforto. Esse é o primeiro ponto. Um segundo aspecto surge pelo intermédio negacionista da vida que requer, também, ponderar sobre o sentido da morte, pois ela nunca esteve tão presente e, ao mesmo tempo, ausente.

Um dos nossos grandes desafio de hoje é esse: a busca por caminhos menos dolorosos que nos façam perceber o tempo que somos para além das relações mercadológicas capitalistas, neoliberais, sistemático-lineares e que, por vezes, reduzem a vida às codificações binárias onde as forças narcisistas negam a alteridade do outro ${ }^{14}$. De fato, se quisermos nos aproximar de uma visão profunda da vida, distante do consumo frenético do tempo, precisamos reaprender a sentir nosso corpo como parte do mundo e, sob tal perspectiva existencial, perceber que somos o próprio tempo.

Se nós somos o próprio tempo, somos, portanto, o grande mediador de nós mesmos. A respeito dessa afirmação, Santo Agostinho, por exemplo, nos esclarece que a percepção de "três tempos" (passado, presente e futuro) é enganosa, pois nos subtrai da dimensão temporal que somos (AGOSTINHO, 1974). O que acontece é que deixamos os "sentidos" genéricos dominar nosso tempo e, por assim dizer, permitimos ser subordinados ao ponto de nos flagelarmos por uma tarefa não bem sucessiva 
no trabalho, por exemplo.

O tempo, nesse momento, deixa de ser uma experiência viva do corpo para se tornar uma modalidade quantitativa da vida. Para Han (2017, p. 33 ), isso tudo tem uma profunda relação com as mudanças de paradigmas de uma antiga "sociedade disciplinar", evidenciada por Michel Foucault, para uma "sociedade do desempenho" que a todo o momento reafirma a expressão yes, we can. No entanto, infelizmente, em muitos casos, a vaidade egocêntrica não nos permite tal compreensão.

Em meio a toda essa agitação do mundo moderno-tecnológico-egosantificado, são raros os momentos que paramos para refletir a respeito do tempo e de sua influência em nossas vidas. Na verdade, acredita-se que o tempo é algo externo ao corpo, reduzido tão somente a matematização do relógio. Daí a ideia enganosa de tempo evidenciada por Agostinho (1974). No isolamento pandêmico, o tempo vem se apresentando como ele é, transcendente do relógio e manifestado pelo isolamento; a quietude, a solidão imposta por esse evento catastrófico viral-global que nos lança à um outro comportamento em relação ao sentido da vida e da experiência com o tempo.

Perceber que somos o próprio tempo e que, por assim dizer, toda nossa educação codificada na linguagem do sistema financeiro global é uma falácia meritocrática que, sistematicamente, nos lança a uma experiência genérica do tempo e, portanto, de nós mesmos, é exigir de nós, enquanto indivíduos e coletivo, o esclarecimento de que existe uma fenda abissal entre corpo e mundo que precisa ser "resgatada" em prol de uma melhor compreensão de si-no-mundo. Em outras palavras, trata-se de trazer à reflexão uma pedagogia existencial na qual corpo e mundo não sejam encarados como dimensões distintas, mas que repousam na coexistencialidade mediada pela experiência corpórea do tempo.

A casa, por exemplo, nosso primeiro sentido de mundo, aliás, nosso primeiro mundo, conforme Bachelard (1998) é, quase sempre, para muitos atualmente, essencialmente o espaço do "tempo de descanso" depois de um longo dia de trabalho, ponto fixo da migração pendular. Mas, agora, em tempos de pandemias, há uma nova implicação geográfica e existencial que exige do corpo (enquanto forma de existência e consciência de mundo) uma outra postura de entendimento a respeito de si mesmo e do tempo que, agora, tem um outro sentido.

Nossa educação, infelizmente, não nos direciona ao entendimento da casa como "habitação", conforme entende Barchelard (1998), mas como domínio de nossas vaidades egosantificadas em nome do livramento do caos que o mundo "lá fora" oferece. Em outras palavras, aprendemos a reduzir o espaço da casa, do corpo, tempo e mundo à valores de satisfação imediata e de imediatização, pois se

\section{GenGrafaress}

Revista do Programa de Pós-Graduação em Geografia e do Departamento de Geografia da UFES

Janeiro-لunho, 2021

ISSN 2175-3709 


\section{GEOGRAFARESO}

Revista do Programa de Pós-Graduação em Geografia e do Departamento de Geografia da UFES

Janeiro-Junho, 2021

ISSN 2175-3709 reproduz por meio de diversos mecanismos que são, não somente materiais, mas, sobretudo, mecanismos simbólicos. Há necessidade, portanto, de percorremos pelo sentido da casa como espaço primeiro de nossa existência, considerando o tempo como potência do ser.

\section{O SENTIDO DA CASA}

"A proibição deixa inquieto Adão..."

Kierkegaard (1968, p. 48).

Casa, habitação primeira, nos conduz em seu espaço para o sentido da vida, do mundo, do que somos. Casa é liberdade na medida em que manifestamos nossa vontade de poder ser. Daí mesmo emerge uma questão dupla: 1) pessoas que se sentem bem estando em casa e outras que, antes mesmo da pandemia, já não se sentia em casa justamente por que, ao invés de ser um espaço de liberdade, já era um espaço de prisão (SILVA, 2020).

Precisamos considerar também a implicação existencial da negação imposta pela pandemia. O filósofo dinamarquês Søren Kierkegaard, traz em sua obra $O$ conceito de angústia, um exemplo muito comum a respeito da negação. Deus nega à Adão o acesso a "fruta proibida" e, ao mesmo tempo, desperta em Adão a "possibilidade de poder", no sentido no qual, conforme Kierkegaard (1968, p. 48), a negação carrega consigo a angústia ou inquietude da liberdade, "como uma forma superior de ignorância, como expressão elevada da angústia, visto que, a este nível mais alto, a angústia existe e não existe. Adão tem amor e foge dela".

A fuga deve ser compreendida não como distanciamento do "perigo", do que foi negado, mas uma aproximação com o que foi negado como expressão da possibilidade de poder. A fuga é uma forma vaidosa de encarar a negação. À vista disso, assim mesmo como a negação do acesso ao fruto provocou a inquietude em Adão, os horários restritivos e todas as medidas para que as pessoas fiquem em suas casas, surgem como negação, provocando, ainda mais, o despertar da "possibilidade poder", que fala Kierkegaard (1968).

Evidentemente que se trata de contextos diferentes, portanto, significa trazer o sentido de negação como forma de compreender a razão das pessoas de estarem simplesmente se aglomerando como se nada estivesse acontecendo. É um puro caso de vaidade que cegamente, mas não inconscientemente, que anula a si mesmo e o outro na afirmação de uma possibilidade que é negada. A "alteridade", como interpreta Lévinas (1997), esvazia-se como areia nas mãos colocando em cheque o sentido de "responsabilidade", conforme entende Sartre (2014a). É a pura corporificação do conceito de "amor líquido" de Habermas (2004) que se manifestam nos bares, restaurantes e casas de shows superlotados

Um outro ponto interessante é o fato de que nossa casa, além de ser o espaço que le- 
gitima a negação e, portanto, é necessário compreender esse fenômeno a partir de uma autorreflexão ou autocrítica, há também que considerar a vontade de fuga de um espaço que, até então, era particular, mas, agora, é público, na medida em que, em uma tela de computador, vinte pessoas invadem simultaneamente meu espaço.

A casa, do ponto de vista psicológico, não é mais meu espaço seguro, pois agora é um espaço invadido e pior, com meu consentimento. É um paradoxo. O mundo frenético do trabalho habita paradoxalmente meu lugar que, aos poucos, perde seu sentido de lugar. A casa, lugar seguro do tempo que é ou deveria ser nosso, agora está cotidianamente aberto ao público, identidade confusa.

Se para Tuan (2011, p. 12), "lugar é uma parada ou pausa no movimento", sendo algo que nos "permite a localização para tornar o lugar o centro de significados que organiza o espaço do entorno", então podemos dizer que nossa casa, como lugar invadido conscientemente e, portanto, paradoxal, começa a ganhar um novo reordenamento onde o corpo estranha a si mesmo e a própria casa enquanto lugar. Só para se ter uma ideia, há pessoas que, ao finalizarem suas atividades de trabalho, saem para rua como se estivessem voltando para casa, apesar de já estarem em suas casas.

Perde-se, por assim dizer, a familiaridade com a casa. Como o "mundo lá fora" sem- pre foi agitado é preferível uma fuga para o encontro ao que antes era estranho e agora familiar, do que com o familiar que agora provoca estranheza. Negar a saída de alguém nestas condições é o estopim para mais aglomeração e, por conseguinte, aumento de casos de contaminação ${ }^{15}$.

Outra maneira de fuga relaciona-se com a esperança do trabalho realizado freneticamente juntamente com a apropriação de informações excessivas aliadas às múltiplas tarefas como forma de "lidar" com o tempo ou com uma possível "falta" de tempo, o que provocaria possíveis casos de ansiedades e, por conseguintes, casos depressivos. Conforme Pantoja (2020, p. 100) "a depressão (e correlato pânico) é esta queda, este afundamento por dizermos "sim" para toda a multiplicidade obscena de referências, de figuras pandêmicas que povoam nossos lugares, de caminhos/ descaminhos a seguir/desviar/ barrar".

$\mathrm{Na}$ verdade, é justamente por não sabermos lidar com as emoções que nos tornamos vítimas de nós mesmos. Estamos falando de uma sociedade onde "homens" aprendem, por exemplo, que "chorar é coisa de mulher". Evidentemente que se trata de um absurdo, mas a realidade é essa e tem a ver como nossas bases históricas e educacionais do patriarcado estrutural, sustentada por uma classe média, conforme Souza (2019). Um "infarto da alma", como diria Han (2017), que vem, no caso do Brasil,
15. Não se trata, de forma alguma, em dizer que medidas de isolamento social não deveriam ser mais adotados, mas de evidenciar uma possível problemática que chama atenção por meios dos problemas psicológicos e existenciais que podem, ou já estão, se agravando.

\section{Gengrafaress}

Revista do Programa de Pós-Graduação em Geografia e do Departamento de Geografia da UFES

Janeiro-Junho, 2021

ISSN 2175-3709 


\section{GEOGRAFARESS}

Revista do Programa de Pós-Graduação em Geografia e do Departamento de Geografia da UFES

Janeiro-Junho, 2021

ISSN 2175-3709 desde muito tempo e que hoje surge como uma espécie de "soco no estômago". Logo, a atual pandemia evidência outras "pandemias" que, até então, estavam incubadas em nossa formação educacional e, inclusive, humana.

Dessa maneira, podemo-nos pergunta o seguinte: de um modo geral, o que aprendemos e ou estamos aprendendo em tempos de COVID-19? Eu posso dizer que esse artigo é fruto dessas inquietações e, por assim dizer, já respondo à pergunta. No entanto, pensar o coletivo, evidentemente sem negar o individual, é mais interessante, nesse momento, ao modo que eu posso obedecer sagradamente às regras para não proliferação do vírus, mas isso pouco importa se meus vizinhos, amigos e pessoas de um modo geral não praticam tais medidas de prevenção.

É uma consciência que pode levar à consciência de que tudo está, mesmo que aparentemente, bem. Então, o que estamos aprendendo com tudo isso? Falava-se que até final de 2020, íamos aprender algo com o vírus mortal, mas, até agora, o que me parece é que isso ainda faz parte de um processo a ser efetivado pelo estatuto histórico de nossa sociedade. Em vista disso, creio que até mesmo a teoria de que aprendemos muito mais pela dor e sofrimento tenha caído por terra. Aprender é um processo que leva tempo.

Durante séculos aprendemos tudo que estamos fazendo hoje e não é um vírus que magicamente irá transformar isso, elevando-nos a uma sociedade mais consciente, ética ou menos desigual. Bolsonaro, por exemplo, todo o dia desdenha das vidas ceifadas pela COVID-19. Isso porque, ironicamente falando, ele é o "Presidente do Brasil". A respeito disso, o que se faz? Nada. Estamos, aparentemente, anestesiados. Ao mesmo, ele continua na presidência em uma situação de pandêmica cada vez mais catastrófica. Repito: o que estamos aprendendo com tudo isso?

O fato é que estamos camuflando nossas angústias cotidianamente ao nos arriscarmos em locais congestionados de pessoas. Eu me incluo por que faço parte dessa sociedade e de pouca valia seria colocar-me em um pedestal livre de qualquer pecado. $\mathrm{O}$ que nos vale é uma consciência educacional capaz de iluminar àquilo que está sendo cada vez abafado pelo atual projeto de governo bolsonarista: que é de reduzir ao máximo nossa humanidade à fatores quantitativos do mercado financeiro, ceifando a esperança de viver e, por conseguinte, castrando a alegria, ao modo que aleija toda forma de motricidade do corpo pelos espaços cotidianos. Reduz o sentido da vida ao abismo das incertezas.

Por essa razão, Frankl (1967), que foi perseguido e condenado pelo regime nazista, nos ensina o sentido da vida e da esperança de viver, dando-nos a responsabilidade de consciência mediante aquilo que faz sorrir, a razão de viver. Diante das atuais situações que provocam o adoecimento da alma e do corpo, o próprio sentido de alegria esvazia-se perante as 
tantas notícias que envolvem, hoje, todas as dimensões da sociedade brasileira. Teremos que aprender, de novo, a nos alegrar?

$\mathrm{O}$ número expressivo de pessoas em ambientes festivos não é sinal de alegria, mas de desespero. A festa é só uma estratégia, ainda que falha, de camuflar a angústia (SARTRE, 2014a). Partindo desse pressuposto, podemos compreender a importância da filosofia existencialista como forma de prática humanista, sobretudo hoje. Tudo isso, de alguma maneira, nos afeta, se partimos do princípio no qual, segundo Chauí (2002, p. 155), "nosso corpo não é uma máquina de músculos e nervos ligados por relações de causalidade e observável do exterior, mas é interioridade que se exterioriza, é e faz sentido". Essa perspectiva é um modo de compreender ou se aproximar ao máximo possível de alguns efeitos provocados pela atual pandemia.

Por esse ponto de vista, precisamos ir para além das visões puramente materialistas da existência; fala-se de processos estruturais e simbólicos que atravessam nossa alma e afetam nossos corpos, não de forma determinante, mas, digamos, de forma que pensemos em outro sentido de humanidade, rumo para uma pedagogia que reclama o seu lugar, de modo que dimensões como angústia e solitude apareçam para nós sem grandes estranhezas e, inclusive, saibamos lidar com essas emoções.

A angústia, nesse sentido, é uma das dimensões da existência humana com a qual precisamos dialogar, refletir e, sobretudo, compreender em um sentido interpretativo no qual o "eu" possa se fazer presente para além de mim mesmo. Esse exercício hermenêutico é uma proposta reflexiva de se auto avaliar mediante as transformações do corpo e do mundo propostas pelas novas circunstancialidades. É, de certa maneira, um distanciamento do ego que tudo quer personificar e transforma à sua medida constante.

Estar em casa, por assim dizer, é uma atitude existencial e, inclusive humanista, mesmo que não se tenha muito noção disso. Daí a necessidade de esboçarmos reflexões que nos estimulem a repensar o mundo de forma integrada e em sua complexidade tal qual se faz desvelar para o ser que o habita, ou seja, um mundo gestado em seus problemas, porém, não apartado da esperança. Tal singularidade que somos pode, por vezes, gestar um sentimento de desconforto, como se estivéssemos exilados em nós mesmos. Daí a importância de considerarmos corpo-mundo e suas implicações existência em tempos sombrios de pandemia, justamente, também, por se tratar de uma questão necro-existencial financiada pela política da morte bolsonarista.

Uma preparação neste sentido é necessária ao modo em que, constantemente, nos encontramos enclausurados em meio à quatro paredes. No entanto, ainda sim, é muito sim-

\section{GEOGRAFARESO}

Revista do Programa de Pós-Graduação em Geografia e do Departamento de Geografia da UFES

Janeiro-Junho, 2021

ISSN 2175-3709 


\section{GEOGRAFARESO}

Revista do Programa de Pós-Graduação em Geografia e do Departamento de Geografia da UFES

Janeiro-Junho, 2021

ISSN 2175-3709 ples pensar que o espaço determinado por quatro paredes é um fator apriorístico para a solitude e angústia, ao modo que, se partirmos exclusivamente deste pressuposto materialista, estaríamos em certo sentido reduzindo a complexidade dos efeitos pandêmicos em nossas vidas (SILVA, 2020).

Em síntese, o sentido da casa é a tese na qual a negação, conforme Kierkegaard (1967), revela um modo de existência paradoxal que ora quer um lugar seguro (conforme o sentido Bachelardiano de casa) e o próprio sentido de lugar (conforme Yi-Fu Tuan), e ora, neste momento de pandemia, nos lança ao público. Um atravessamento do público paradoxalmente permissivo em um espaço (nosso quarto, sala, etc) sagrado justamente por não permitir o esvaziamento ao público. Acontece que o sentindo de casa, agora, é negação e, portanto, nos provoca agonia e angústia que foge, em muitos casos, de nossa educação familiar.

\section{CONSIDERAÇÕES FINAIS OU UM MERGULHADO EM SI MESMO}

"Assim acontece com vocês: agora é hora de tristeza para vocês, mas eu os verei outra vez, e vocês se alegrarão, e ninguém tirará essa alegria de vocês". João (16:22).

A parábola de João não é um desânimo, mas um despertar para consciência dos fatos. Hoje, estamos angustiados, ansiosos e depressivos com tan- tos descasos com a pandemia. Sentimentos que aprendemos, desde muito cedo, a negar. Desde nossa infância aprendemos a disfarçar nossas angústias e inquietações, enfim, nossas emoções. Aprendemos a ser "fortes" e que ficar triste é sinal de "fraqueza". De um modo geral, conforme Sartre (2014b), o aparente disfarce das emoções é, na verdade, contribuir para o desconhecimento das mesmas, ou seja, de nós mesmos.

As emoções, conforme o filósofo refere-se ao tratamento que ofertamos a nós mesmo no mundo, de modo a considerar as transformações de comportamento do próprio corpo. Em outra obra, $O$ existencialismo é um humanismo, Sartre (2014a) relaciona o sentido de "responsabilidade" com de "angústia", tratando a primeira como consciência prática da segunda, ou seja, trazendo a importância do compromisso com o coletivo sem negar a individualidade. Isso vale muito para os dias atuais.

Em outras palavras, nossa educação ocidental, considerando a dimensão emocional e a perspectiva psicológica para além do inconsciente, tal como defende Frankl (1967), ainda é muito ínfima em nossa realidade brasileira. As consequências são evidentes hoje, onde o corpo, mundo e tempo, despertam-se exigentes de novos horizontes epistemológicos da vida, isto é, outro sentido de vida, evidentemente cada à sua maneira, e que se confrontam com nossa formação inicial. 
Byung-Chu Han em Sociedade do cansaço, afirma que o século XX e XXI não se caracteriza por uma crise viral, mas neural. Por outro lado, o filósofo não observa que em realidade de tendência autoritárias, como é o caso do Brasil, a questão viral ainda é um problema, ao modo que a ignorância e negligências por parte do governo bolsonarista alia-se a movimentos fanáti$\cos$ que esquizofrenicamente atacam a ciência, a produção e aplicação de vacinas. E isso, talvez, seja o suficiente para entender que a pandemia no Brasil é, na verdade, um projeto contra a vida.

Nesse contexto, a evolução da técnica e ciência pouco importa para combater uma crise viral, haja vista que não se trata de uma "crise viral", mas de um projeto de governo que nega suas responsabilidades para com a população em prol da vida, sobretudo com aquelas/es mais vulneráveis. Evidentemente que o governo bolsonarista não trabalha só, pois se articula sistematicamente com alguns grupos religiosos que, em "nome de Deus", cultuam a ignorância e a violência físico-simbólica contra aqueles/as que trabalham em prol da pesquisa e produção de vacinas.

São os "negacionistas" e seus efeitos são catastróficos. Logo, vivenciamos uma crise viral e, essencialmente, ética, tanto por parte de alguns grupos fanáticos "cristãos" quanto por parte do Governo Federal que, constantemente, flertam com práticas fascistas. Uma ordem se estabelece porque cria uma certa "legitimidade" para que selecionados grupos negacionistas, tal como a classe média-cristã brasileira, se autodeclarem herdeiros de um trono já em ruínas, acreditando pertenceram a elite. Esse processo que é estrutural e simbólico, segundo Souza (2019), ecoa para diversas dimensões da sociedade, inclusive, em nosso caso, para a educação.

Em suma, a discursos que estimulam a fuga da realidade é a marca do governo bolsonarista que usa, tranquilamente a naturalizando, toda angústia de uma classe média ressentida por não alcançar os números bancários daqueles que tentam veneram e eticamente se espelham: a elite. Dimensões essas que, por vezes, nos permitem pensar que boa parte dos problemas gestados pelo COVID-19, sendo eles físicos-neurais, poderiam ser evitados se houvesse medidas médico-sanitaristas eficientes. A pandemia que nos assombra há pelo menos 1 ano é, portanto, um projeto político que envolve a aliança entre governo, grupos evangélicos fanáticos negacionistas e nossa mínima capacidade de refletir a respeito de nossa realidade.

De um modo geral, essa estrutura de poder que flerta com a morte de sua própria população não pode ser desconsiderada em nossas interpretações, sobretudo se quisermos dialogar a respeito da existência em tempos de pandemia. Ou seja, COVID-19 é um vírus que fatalmente atinge o organismo humano. Pandemia, entendida

\section{GenGRAFARESO}

Revista do Programa de Pós-Graduação em Geografia e do Departamento de Geografia da UFES

لaneiro-Junho, 2021

ISSN 2175-3709 
GERGRAFARESO

Revista do Programa de

Pós-Graduação em Geografia e do Departamento de Geografia da UFES

Janeiro-Junho, 2021

ISSN 2175-3709 aqui, é o COVID-19 articulado politicamente o que, por sua vez, desencadeia outras pandemias que, até então, estavam veladas. São dimensões negativas, como os ataques a ciência, que atingem de forma perversa nosso sentido de vida, nos provocando a repensar o sentido do corpo, mundo e suas implicações existenciais.

As dimensões geográficas, consideradas por muitos como "escalas pequenas", tal como o espaço da casa, estão inseridas nesse projeto de governo que pouco se importa de como sua própria população está cuidando de si nesta situação pandêmica. Cuidar de si é abrir mão das relações narcisistas e abraçar, em uma "relação de ombro", como diria Merleau-Ponty (1994), um outro sentido de vida em prol da vida digna. É um projeto possível que recorre a um humanismo que não é somente "humano", mas, sobretudo, cosmológico, tal como desenvolve, por exemplo, Krenak (2020).

Eu nunca senti meu corpo como estou sentido agora. As horas de aulas sentado na cadeira doem minhas costas, os fones de ouvido fazem meus ouvidos latejar, meus olhos vidrados na tela do computador ardem. E, ainda assim, embora acredite que tenho "sorte" por trabalhar em casa - como dizem alguns - penso que até mesmo esse sentido de "sorte" recorre a uma ideia elitizada que pouco tem a contribuir para um sentido mais amplo à respeito do sentido de espaços significativos, como a casa. Meu quarto foi transformado em sala de aula. Isso não é sorte, é apenas mais uma forma de nos adoecer se nada for feito efetivamente. Daí nos perguntarmos, novamente, conforme a letra da música inicial deste artigo/ensaio: "Que mundo estou?" 


\section{REFERÊNCIAS BIBLIOGRÁFICAS}

AGOSTINHO, S. As confissões. Trad. Frederico Ozanam Pessoa de Barros. São Paulo: Edameris, 1964.

BACHELARD, G. A poética do espaço. São Paulo: Martins Fontes, 1998.

BÍBLIA, A. T. Provérbios. In: BÍBLIA. Sagrada Bíblia Católica: Antigo e Novo Testamento. Tradução: José Simão. São Paulo: Sociedade Bíblica de Aparecida, 2008. p. 202-203.

BRAGA, A. R. P. Tédio e sentido na pandemia: uma análise a partir do pensamento de Viktor Frankl. Complexitas-Revista de Filosofia Temática, v. 5, n. 1, p. 67-79, 2020.

BAUMAN, Z. Amor líquido: sobre a fragilidade dos laços humanos. Rio de Janeiro: Jorge Zahar Editor, 2004.

CHAUÍ, M. Experiência do Pensamento: ensaios sobre a obra de Merleau-Ponty. São Paulo: Martins Fontes, 2002.

DARDEL, E. O Homem e a Terra: natureza da realidade geográfica . Tradução Werther Holzer. São Paulo: Perspectiva, 2015.

FRANKL, V. Em busca de sentido: um psicólogo no campo de concentração. Trad. Walter O. Schlupp e Crlos C. Aveline. Porto Alegre: Sulina, 1987.

FREITAS, F. S. A Perspectiva Biopolitica da Medicina Social: SUS, PSF, Neoliberalismo e Pandemia. Kínesis-Revista de Estudos dos Pós-Graduandos em Filosofia, v. 12, n. 31, p. 186-213, 2020a.

(Neo)liberalismo e homo oeconomicus como perspectivas biopolíticas. Occursus, v. 5, n. 1, p. 270-290, 2020 b.

HARVEY, D. A condiçăo pós-moderna. Săo Paulo, Loyola, 1993.

HUSSERL, E. Ideias para uma fenomenologia pura e para uma filosofia fenomenológica: introdução geral à fenomenologia pura. São Paulo: Idéias \& Letras, 2006.

HAN, B-C. Sociedade do cansaço. Trad. Enio Paulo Giachini. Rio de Janeiro: Vozes, 2017.

KIERKEGAARD, S. O conceito de Angústia. Lisboa: Hemus editora, 1968.

KRENAK, A. A vida não é útil. São Paulo: Companhia das Letras, 2020.

KOLA, L. et al. COVID-19 mental health impact and responses in low-income and middle-income countries: reimagining global mental health. The Lancet Psychiatry, 2021.

\section{GEOGRAFARESO}

Revista do Programa de Pós-Graduação em Geografia e do Departamento de Geografia da UFES

Janeiro-Junho, 2021

ISSN 2175-3709 
GERGRAFARESO

Revista do Programa de

Pós-Graduação em Geografia e do Departamento de Geografia da UFES

Janeiro-Junho, 2021

ISSN 2175-3709
LÉVINAS, E. Entre Nós. Ensaios sobre a alteridade. $3^{\mathrm{a}}$. ed. Petrópolis: Vozes, 1997.

MERLEAU-PONTY, M. Fenomenologia da percepção. São Paulo: Martins Fontes, 1994.

MARANDOLA JR, E. Olhar encarnado, geografias em formas-devida. GeoTextos, v. 14, n. 2, 2018.

NIETZSCHE, F. O anticristo. São Paulo: Companhia das Letras, 2007.

SARTRE, J.-S. O existencialismo é um humanismo. Trad. de João Batista Kreuch. $3^{\text {a }}$ Ed. Rio de Janeiro: Vozes editora, 2014a.

Esboço para uma teoria das emoções. Tradução de Paulo Neves. Porto Alegre: L\&PM, 2014b.

PANTOJA, W. W. R. "Te situa”: desorientações geográficas em lugares pandêmicos. In: COUTO, A. C. O.; MENDES, L. A. S. (Orgs.) Reflexões geográficas em tempos de pandemia. Ananindeua, PA: Itacaiúnas, 2020.

SOUZA, J. A elite do atraso. Rio de Janeiro: Estação Brasil, 2019.

SILVA, F. K. R. Vida, Morte e Cuidado: uma grafia acerca da existência em tempos de COVID-19. In: COUTO, A. C. O.; MENDES, L. A. S. (Orgs.) Reflexões geográficas em tempos de pandemia. Ananindeua, PA: Itacaiúnas, 2020.

TUAN, Yi-Fu. Espaço e lugar: a perspectiva experiência. Trad. Lívia de oliveira. Londrina: Eduel. 2013. 